\title{
Two GRAND Old LADIES FACE TO FACE: THE UNITED KINGDOM AND THE UNITED STATES OF AMERICA CONSTITUTIONS COMPARED
}

\author{
Mario Patrono* and Justin O Frosini ${ }^{* * *}$
}

This article discusses the Constitution of the United Kingdom and then draws some comparisons between it and the Constitution of the United States of America. It touches on issues such as how the United Kingdom's commitment to parliamentary sovereignty has been affected by the country's relationship with the European Union.

\section{A BRIEF PROLOGUE}

The Constitution of the United Kingdom and that of the United States of America are very different. The Constitution of the United Kingdom is a "sociological" constitution, born in the heart of British society as, perhaps, its most sophisticated quintessence, at least on political grounds. In contrast, the Constitution of the United States of America is the fruit of the work done "at the table" by eminent political thinkers who, on a nice day and after a long debate and lengthy negotiations, wrote in a document their ideas on government. This factor alone, reflecting the different "nature" of the two constitutions, is worthy of analysis for those who want to attempt a comparison between them. In addition to this, the Constitution of the United States would seem to be, in some respects, exactly what the United Kingdom's Constitution is not, and did not want to be. The judicial review of legislation, for example, seems to have been taken from the reservoir of English judicial experience pre-1688, an experience which, here in New Zealand, had a resounding but sterile revival during the 1970 s.

* Emeritus Professor of Comparative Public Law and European Law at Rome University "La Sapienza". Former Professor of Constitutional Law at Padova (Padua) University, where he was Director of the Department of Legal Studies. Visiting Professor at Victoria University of Wellington, Faculty of Law. Submitted with affection and respect for my friend, Professor Bill Atkin.

** Assistant Professor of Public Law at the Bocconi University, Milan. 
However, the main difficulties with comparison lie elsewhere. Both constitutions are not just "old", but may be defined as "ancient". Certainly, the United Kingdom's Constitution is ancient: its origins have been lost in the mists of time. But, the United States' Constitution can also be characterised as ancient; written in 1787 by men who had been trained, culturally speaking, at least 20 years before in a world that was light years away from our own. These two constitutions have recently come into contact - in different ways - with the various facets of a super-connected world. Strangely, these challenges seem to be better absorbed by the United States of America's Constitution (although it would appear unable to escape the prison of its written words), compared to the United Kingdom's Constitution, despite its supposedly flexible nature. The Constitution of the United States of America, almost by a miracle of history, was born entrenched but at the same time "elastic": its core structures seem to have the same capability of "absorption" of political social stress that the most modern earthquake-proof buildings have in respect to seismic activity. The United Kingdom's Constitution does not have this same elasticity: as a boat without a keel it is in danger of being ruined against the rocks.

The globalised world excites nationalistic forces to expand, while increasingly intense international bonds severely test the "sacred" principle of sovereignty of Parliament. Thus, despite the attempts made by the British Government in the 1990s and early 2000s to prevent the jolts of such international pressure by preparing the country's political system through a series of constitutional reforms, the effects of growing destabilisation have not been slow to emerge. As if to illustrate this, in the May 2015 general election the Scottish National Party won 56 of the 59 seats in Scotland - a triumph which may be decisive in driving the Scots from the Union. Moreover, the once lauded, but now perhaps arcane, Westminster model - which encourages (sometimes reluctant) voters along the usual path of a two party system - appears to show some inadequacy in its ability to focus on and interpret public opinion in response to a world in rapid and feverish evolution. On the other hand, the mouthfuls given to Member States by the European Union (EU) are sometimes very bitterly swallowed by Britain. For example, the United Kingdom Independence Party, a political group advocating repatriation of (supposedly) confiscated British sovereignty, essentially by the EU, obtained approximately 10 per cent of all votes. This is a further indicator of a potential British opt-out from the EU which reinforces the recurrent temptation of the government to cut its mooring with the Union.

So, the constitutional lawyer when observing two constitutions in motion, more so of the United Kingdom's Constitution, can certainly not take refuge in the comfortable position of an analysis of a "synchronic" type (that is, purely formal, like a snapshot today of something whose appearance may change tomorrow). He must go further to take account of changes and trends in the two systems; a tempting but difficult task.

\section{THE BRITISH CONSTITUTION}

We know, English nouns (and pronouns that accompany them) have, as a rule, no gender connection as opposed to other languages. In spite of this, we would like, just for a few moments, to 
refer to the British Constitution as female. And therefore, observed while going hand-in-hand with the sovereignty of Parliament, "She" - the British Constitution - appears to be surrounded, as well as the ladies of great class and beauty, by an aura of mystery: a bizarre mystery. We know what "She" is in the sense that we know what "her" core principles are - parliamentary supremacy, the rule of law and the civil liberties. But, surprisingly, we do not know whether "She" exists or not. Two factors play a role in this mystery. One is the sovereignty of Parliament which keeps "her" suspended between life and death, between being and not being. Acts of Parliament, as its own inherent attribute, have the capacity to dismantle "her" anytime, anywhere. Vocabulary is important as well, and the mystery's solution depends pre-eminently on the meaning of the word "constitution". Some scholars say that, according to the American and French meaning of the word, ${ }^{1}$ the United Kingdom has no constitution. ${ }^{2}$ But by giving the word "constitution" a wider meaning (i) a body of fundamental principles and established precedents according to which a state is governed, and (ii) in a way linked with enjoyed basic liberties - it is evident that the United Kingdom does have a constitution.

It is usually stated that, unlike the majority of the countries of the world, the United Kingdom has an unwritten constitution. ${ }^{3}$ This statement is clearly inaccurate. With regard to the British Constitution it appears more appropriate to speak of a non-codified constitution.

1 See, among others, KC Wheare Modern Constitutions (Oxford University Press, London, 1960) at 21. Article 16 of the French Declaration of Rights 1789 felicitously summarises the French and American concept of a "constitution": "A society in which the observance of the law is not assured, nor the separation of powers defined, has no constitution at all". The French and American concepts of constitution emphasise the two elements of "division" as the rule organising power and the special protection afforded to certain rights, both acting in synergy as instruments defending citizens against arbitrary uses of public powers. However, the "classic" English constitutionalists prefer instead to underline that in the United Kingdom, Parliament is legibus solutus, (that is, sovereign and all-powerful), that the British system is based not on the "division" but on the "fusion" of powers, and that the British Constitution does not offer any special protection for fundamental rights (on these statements, see Giovanni Sartori "Constitutionalism. A Preliminary Discussion" (1962) 56 American Political Science Review 855). It is clear, as we shall see below, that compared to the situation at the times when Blackstone, Dicey, Jennings and Bagehot were writing, the United Kingdom constitutional system appears today modified, more or less, on each of the three points indicated - division of powers, protection of fundamental rights and the sovereignty of Parliament. Above all, this is owed to two rulings by the House of Lords: $R v$ Secretary of State for Transport, ex parte Factortame Ltd [1990] 2 AC 85 (HL); and $R v$ Secretary of State for Transport, ex parte Factortame Ltd (No 2) [1991] 1 AC 603 (ECJ and HL). The United Kingdom Constitution was also modified by the application in 2000 of the Human Rights Act 1998 and finally the Constitutional Reform Act 2005. For a thorough formal analysis of today's British Constitution and its various sources, see Tarunabh Khaitan "'Constitution' as a Statutory Term" (2013) 129 LQR 589.

2 ECS Wade and AV Bradley Constitutional and Administrative Law (10th ed, Longman, London, 1985) at 4: "In this sense of the word, the United Kingdom of Great Britain and Northern Ireland has no constitution."

3 Ivor Jennings The Law and the Constitution (5th ed, University of London Press, London, 1959) at 4-22. See also O Hood Phillips The Principles of English Law and the Constitution (Sweet \& Maxwell, London, 1939) at 208. 
As a matter of fact, the English Constitution derives from both written and unwritten sources. The written sources go back to the Magna Carta of 1215, still included in the "non-codified" constitution of the United Kingdom. Today the majority of the provisions of the Magna Carta are no longer in force; nevertheless it is a document that contributes to this "non-codified" constitution.

There is a series of Acts of Parliament that were passed in close succession which also comprise the "written" part of the constitution of the United Kingdom: from the Petition of Rights in 1610 1628 to the Act of Settlement in 1701, through the Habeas Corpus Act in 1679, the Bill of Rights in 1689 and the Toleration Act (in force by 1689). Other, more recent "constitutional" statutes, ${ }^{4}$ such as the European Communities Act 1972, are now flanked and integrated in various ways by the European Union Act 2011 (EUA) and the Human Rights Act 1998.

Side by side with the written sources are the unwritten sources of the British Constitution. These comprise the constitutional conventions which can perhaps be termed constitutional traditions or customs. The essential elements of these conventions are that the opinion juris ac necessitatis (that is to say, the understanding that the established behavior must be considered legal), and the usus (that is to say, that the set manner of behaviour is repeated).

Then there are the royal prerogatives, namely the powers which formally reside in the Crown, but which in fact are mostly exercised by the Cabinet.

Among the sources which contribute towards the composition of the "non-codified" Constitution of the United Kingdom are various sources of European law. This may perhaps seem strange of a country that likes to define itself as "Eurosceptical". However, if one looks through any textbook of English constitutional and administrative law, there is no doubt that the EU sources fall within the "non-codified" Constitution of the United Kingdom. The same can be said of the 1950 European Convention for the Protection of Human Rights and Fundamental Freedoms (ECHR), which also falls within this category of constitutional sources. ${ }^{5}$ The ECHR, strongly desired by the British Government at the time of its promulgation, places great emphasis on civil and political rights, but it does not recognise economic and social rights. The ECHR was incorporated into the British legal system in 1998 through the Human Rights Act (which came into effect in 2000), thus becoming part of the British Constitution.

By way of preface to the comparison between the English Constitution and that of the United States of America undertaken later in this article, an important difference to note early is that the United States of America has a Constitution that is codified, rigid, and entrenched by judicial review. The text of the United States federal Constitution can be defined as an "extensive

4 "Constitutional statutes" is a term coined by Laws J in Thoburn v Sunderland City Council [2002] EWHC 195 (Admin), [2003] QB 151 at [62]-[64].

5 Convention for the Protection of Human Rights and Fundamental Freedoms 213 UNTS 222 (opened for signature 4 November 1950, entered into force 3 September 1953). 
constitution" if it is considered together with the Bill of Rights and the other amendments which have intervened over the years. These are two constitutions which are very dissimilar.

It is well known that in western society the law is presented in two different forms: as Common Law and as Civil Law. These are two legal families which present markedly different characteristics, both in formation and in enforcement. They are "the two laws of the western world". Nevertheless there are countries in which these two laws coexist in a variety of ways.

England is the homeland of the Common Law. A trivial error is often made here. It is often assumed that in the common law legal system the main source of law is custom, which thus constitutes the basis of the Common Law. This is not correct. On the contrary, the creation of the Common Law over time was an overcoming of local tradition (of the various laws operating in the different areas of England), following the invasion by the Normans and by William the Conqueror in 1066, and above all implemented by Henry II Plantagenet (1154-1189). Indeed this is considered the date when the Common Law began to be created. The British legal system and the legal systems of other common law countries, even with important differences between them, are legal systems which are based on case law. Therefore, the Common Law is exactly the opposite of a law constituted by local traditions. It is a jus commune of Anglo-Saxon background created through the work of the judges.

At this point it is much more interesting for us to understand how the United Kingdom and United States legal systems operate today from the point of view of Constitutional Law.

One point can be underlined in relation to the United Kingdom: one of the pillars of the British Constitution is the supremacy of Parliament. This makes the United Kingdom unique in comparison to all other civil law and common law countries, including the legal system of the United States. Next, there is a second pillar which we customarily associate with the name of an important Victorian scholar, Albert Venn Dicey: the rule of law. This probably has its true roots during the time of the great jurist and judge Sir Edward Coke, Chief Justice of the Court of Common Pleas, where he was in conflict with James I regarding the relationship between the King, the judges and Parliament.

The supremacy of Parliament is based on the idea that the real representative of sovereignty is precisely Parliament as the legislative body. A paradoxical, but almost proverbial remark says that the English Parliament can do anything except make a man into a woman and a woman into a man. ${ }^{6}$

6 Usually, that paradoxical remark is ascribed to a Swiss scholar of the English constitution, Jean-Louis De Lolme, as written in The Rise and Process of the English Constitution (revised ed, 1838). In this regard see Jennings, above n 3, at 170, where he writes: "De Lolme's remark that Parliament can do anything except make a man into a woman and a woman into a man is often quoted". But the most illustrious quotation of that remark came from Albert Venn Dicey. Just after having posed his "classical" view on Parliament's sovereignty as "the right of Parliament, under the English Constitution, to make or unmake any law whatever, and further, that no person or body is recognised by the law of England as having a right to 
The concept is thus that Parliament is supreme with respect to all other institutions, including the King. Here, again, we could dwell at length on the transition from absolute monarchy to constitutional monarchy up to the current parliamentary monarchy in the United Kingdom. The fact remains that the Glorious Revolution in 1689 is an important transitional point towards achieving the sovereignty of Parliament.

The other pillar of British constitutionalism is the rule of law which states that governmental action must be subject to the law, enforced through judicial review. In comparative law, at times, the attempt is made to assimilate the rule of law to the German concept of Rechtsstaat, the Italian concept of Stato di diritto and if you wish, the principe de légalité in French law. The shared element in the concepts we have mentioned is that they all indicate the common subjection to the law. ${ }^{7}$ But the difference between them is remarkable. The English rule of law contains a strong moral value: the legal defence of civil liberties. By contrast, in other countries, like Germany, Italy, Spain or France, this same moral value has only been incorporated into the corresponding "principle of legality" when, finally, a judicial review of statutes' conformity to the rules, principles and values contained in an entrenched national constitution began to operate.

The supremacy of Parliament and the rule of law are the two pillars of English constitutional law, but it was not always so. At the beginning of the 17th century there was an attempt to make common law prevail over statute law; common law being judge-made law, statute law being laws made by the legislature. At the beginning of the 17th century the famous Dr Bonham's Case was heard in the Court of Common Pleas, with Edward Coke sitting as Chief Justice. ${ }^{8}$ Here, the idea asserted was that not all laws could be enforced; that the only enforceable laws were those which proved "reasonable" and were not "repugnant" to the Common Law; that is, against fundamental common law principles.

override or set aside the legislation of Parliament", Dicey summed up his view "in a grotesque expression which has become almost proverbial: It is a fundamental principle of English lawyers that Parliament can do anything except make a man into a woman and a woman into a man". He attributed the expression to De Lolme: see Albert Venn Dicey An Introduction to the Study of the Law of the Constitution (8th ed, 1915, reprinted Liberty Fund, Indianapolis, 1982) at 3 and following. Personally, we must confess that we are unable to find this "almost proverbial" expression in either of De Lolme's two books, although many other scholars after Dicey and Jennings have persisted in quoting it. It is of no importance. The relevant point here is that De Lolme's "proverbial" remark, widely (and rightly) criticised as "grotesque" as regards its first part, "the Parliament can do anything", has become untrue also in respect of its second part: "except make a man into a woman and a woman into a man". Today, due to the progress in surgical techniques related to gender reassignment, all Parliaments can do this, and do so. On Dicey's (traditional) doctrine of parliamentary sovereignty, see Geoffrey de Q Walker "Dicey's Dubious Dogma of Parliamentary Sovereignty" (1985) 59 ALJ 276; Jeffery Goldsworthy The Sovereignty of Parliament: History and Philosophy (Clarendon Press, Oxford, 1999) especially at 233 and following; and NW Barber The Constitutional State (Oxford University Press, Oxford, 2010) especially at 81 and following.

7 Entick v Carrington (1765) 19 How St Tr 1030, 95 ER 807 (KB).

8 Bonham v College of Physicians (1610) 8 Co Rep 107a, 77 ER 638 (Comm Pleas). 
This view did not find favour in England. What prevailed in the end was the principle of the supremacy of Parliament. In other words, the idea that judges could void Acts of Parliament if they clashed with fundamental principles of the Common Law was rejected in England. In contrast, in the United States this is exactly the principle forming the basis of the judicial review of legislation, which was first asserted with the famous 1803 case of Marbury v Madison. ${ }^{9}$ In that judgment, the United States Federal Supreme Court decided for the first time to invalidate a statute (a part of the 1789 Judiciary Act) which was inconsistent with the Federal Constitution 1787, and in particular with art 3, which concerned judicial power. Therefore, in the United States of America the "sovereign" is not the Congress, but the Constitution.

A second important element of comparison between the United Kingdom and United States legal systems emerges here. The United States Supreme Court, using the same principle which had already appeared two centuries earlier in Dr Bonham's Case, established that judges had the power to scrutinise the constitutionality of state and federal statutes.

At this point a number of things need to be elaborated on. The United States Supreme Court has always, at least officially, denied any connection between Marbury $v$ Madison in 1803 and $\mathrm{Dr}$ Bonham's Case of 200 years earlier. ${ }^{10}$ However there can be no doubt that the Chief Justice of the Supreme Court at that time, John Marshall, had been greatly influenced by Coke's writings and by that case in particular. ${ }^{11}$ Thus there is this subtle fil rouge between British Constitutional Law and

9 Marbury v Madison 5 US 137 (1803).

10 The main ruling that can be cited to refute that Bonham constitutes a precedent for Marbury might be deemed Hurtado v California 110 US 516 (1884), where we find the following passage: "notwithstanding what was attributed to Lord Coke in Bonham's case, 8 Rep. 115, 118a, the omnipotence of Parliament over the common law was absolute, even against common right and reason. The actual and practical security for English liberty against legislative tyranny was the power of a free public opinion represented by the Common." Furthermore, it is underlined that Chief Justice Marshall never cites Coke or the Bonham Case. This statement is inaccurate: in fact Chief Justice Marshall cites Vanhorne's Lessee v Dorrance 2 US 304 (1795) where Coke is amply cited by Justice Paterson.

11 The author who, with greater authority, maintains that John Marshall was influenced by Coke and $D r$ Bonham's Case, is Noah Feldman, Professor at New York University. In his article "The Voidness of Repugnant Statutes: Another Look at the Meaning of Marbury" (2004) 148 Proceedings of the American Philosophical Society 27, he underlines the similarity between the language used by Marshall and that used by Coke. In particular, Feldman refers to the phrase "an act of the legislature repugnant to the constitution is void", and asserts (at 28, emphasis added): "In Marbury, in crafting the classic formulation of the doctrine of judicial review, Chief Justice Marshall adapted the language of the maxim, then more than two hundred years old, that statutes repugnant to reason were void. For 'reason' he substituted the Constitution." Feldman continues by affirming that "Lord Coke, sitting in judgment on the case of one Dr. Bonham, seems to have brought these terms into the vocabulary of English-speaking lawyers" and then cites the most important passage from the Dr Bonham's Case: "[I]t appears in our books, that in many cases, the common law will controul acts of parliament, and sometimes adjudge them to be utterly void: for when an act of parliament is against common right and reason, or repugnant, or impossible to be performed, the common law will controul it, and adjudge such act to be void." According to Feldman the use of the words "repugnant" and "void" eloquently demonstrate the fact that there is a connection between Dr Bonham's Case and Marbury. 
that of the United States which joins the Marbury case and Dr Bonham's Case. The principle adopted in Marbury was not followed in United Kingdom constitutional law, but was destined to function within the American context.

In summary, the presence of the "codified" and rigid Constitution of the United States, the United States Supreme Court has the power to invalidate both a federal and a state statute, when that statute conflicts with the Federal Constitution. This gives rise to a hierarchy of the sources of law with which we are familiar in continental Europe. Here, the image of a pyramid appears with the Constitution as "higher law of the country" at its apex, an image which Hans Kelsen portrayed with his Stufenbau theory (a hierarchical step structure). ${ }^{12}$ This expression "hierarchy of sources" is seldom used in the United States. However, it does in fact exist in the United States, and it has existed from the time of Marbury $v$ Madison.

As Feldman writes (at 30): "[T]he word 'repugnant' is a relatively rare word in legal discourse. When we see it recurring alongside the notion of voidness in these two cases separated by almost two hundred years, we can be certain there is no coincidence." He then proceeds to affirm that "Chief Justice Marshall in Marbury used the familiar, even classical, language of repugnancy and voidness to make a strikingly novel and constitutional point in the American context" (at 31). On the contrary, JW Gough strongly denies any derivation of Marbury from Dr Bonham's Case in his book, Fundamental Law in English Constitutional History (Clarendon Press, Oxford, 1955) at ch XII, especially at 206-207. However, it should be observed that identifying the historical facts whence Marshall CJ was inspired in writing Marbury - and among these, alongside the "precedent" of Dr Bonham's Case, one can include the works preparatory to the Constitution (Edward S Corwin "The Establishment of Judicial Review" (1910) 9 Mich L Rev 102 at 102-103); the precedents established by the Privy Council in the management of colonial legislation (James B Thayer "Origin and Scope of the American Doctrine of Constitutional Law" (1893) 7 Harv L Rev 17 especially at 129); and the attitude of the jurisdictional organs in the single states, preceding the adoption of the federal Constitution or in the period immediately after (see Charles Grove Haines The American Doctrine of Judicial Supremacy (University of California Press, Berkeley, 1932) at 89 and following, and 128 and following). For an overall picture of the historical factors that underpin Marbury see Louis Fisher "Judicial Supremacy: How Did this Far-Fetched Claim Originate?" (paper presented to the American Political Science Association Conference, Washington DC, 3 September 2010). A different problem concerns the legal foundation of judicial review. From this point of view, there is no doubt that judicial review is something new and original in relation to British juridical and political experience that can only be explained within the framework of the federal legal order. To be exact, Chief Justice Marshall finds judicial review concealed among the folds of the Constitution, and discovers it through a penetrating logical and systematic interpretation of the constitutional text: "The government of the United States is of the latter description [that is, it is based on a written Constitution]. The powers of the legislature are defined and limited; and that those limits may not be mistaken, or forgotten, the Constitution is written. To what purpose are powers limited, and to what purpose is that limitation committed to writing, if these limits may, at any time, be passed by those intended to be restrained? ... Certainly all those who have framed written constitutions contemplate them as forming the fundamental and paramount law of the nation, and consequently, the theory of every such government must be, that an act of the legislature, repugnant to the constitution is void. This theory is essentially attached to a written constitution and is, consequently, to be considered, by this court, as one of the fundamental principles of our society."

12 Hans Kelsen General Theory of Law and State (Harvard University Press, Cambridge (Mass), 1949) at 122135. 
Returning to the United Kingdom, we have seen that one of the pillars of the British legal system is the supremacy of Parliament. Does the supremacy of Parliament still exist in the United Kingdom? The answer is "nes": half way between yes and no. "Yes", because even today, from a formal point of view at least, there is almost always in the title of the Acts of Parliament a variously expressed reference to the supremacy of Parliament. More importantly, it should be noted that all or almost all scholarly opinion in the United Kingdom remains firmly convinced - rightly or wrongly that Parliament is still fundamentally sovereign. "No", because over the years numerous reforms have intervened and somewhat diminished and weakened this supremacy.

Sources of EU law are the first element to have weakened, somewhat, the supremacy of Parliament. In a sense, the moment Edward Heath's Conservative Government led the United Kingdom into Europe through the European Communities Act 1972, the first step was taken towards what many commentators define as a weakening of the "classic" supremacy of Parliament. When the United Kingdom joined the European Economic Community (EEC), an established jurisprudence of the European Court of Justice already existed, which contained a number of basic principles concerning the relationship between Community law and domestic law. The principle that is most relevant for the purposes of this article is the supremacy of Community law over the national law of Member States. When the United Kingdom entered the EEC it took note of this situation; under the circumstances it could not have done otherwise. In entering the EEC, the United Kingdom accepted the reality of the presence of a European Court of Justice that was entrusted with the role of interpreting the Treaty itself. The law which emerged in Van Gend en Loos ${ }^{13}$ and in Costa $v$ Enel, ${ }^{14}$ was recognised in the legal system of the United Kingdom by means of the European Communities Act. ${ }^{15}$ In this way, the United Kingdom accepted a sort of restraint on the sovereignty of its Parliament. ${ }^{16}$ This limitation was accepted only gradually and only after English judges had put up a valiant resistance, ${ }^{17}$ similar to the resistance shown by judges of other Member States. ${ }^{18}$

13 Case C-26/62 Van Gend en Loos [1963] ECR 1.

14 Case C-6/64 Costa v Enel [1964] ECR 585.

15 The European Communities Act 1972, along with the European Union (Amendment) Act 2008, implemented the two Lisbon Treaties.

$16 R v$ Secretary of State for Transport, ex parte Factortame Ltd (No 2), above n 1, at 658-659: "If the supremacy within the European Community of Community law over the national law of member states was not always inherent the EEC Treaty ... it was certainly well established in the jurisprudence of the European Court of Justice long before the United Kingdom joined the Community. Thus, whatever limitation of its sovereignty Parliament accepted when it enacted the European Communities Act 1972 was entirely voluntary. Under the terms of the Act of 1972 it has always been clear that it was the duty of a United Kingdom court, when delivering final judgment, to override any rule of national law found to be in conflict with any directly enforceable rule of Community law." In truth, the English courts seem firmly entrenched in defence of the sovereignty of Parliament in spite of the presence of the principle, established by the jurisprudence of the European Court of Justice, of the supremacy of community law over national law. The argument generally adduced to proclaim that the conditions of Parliament's legislative supremacy in the 
United Kingdom necessarily remain in the United Kingdom's hands, is that s 2(4) of the European Communities Act 1972, establishing among other things that "any enactment passed or to be passed, other than one contained in this Part of this Act, shall be construed and have effect subject to the foregoing provisions of this section", contains a rule of interpretation. In this regard Trevor C Hartley writes: "So what does the sentence quoted above mean? What it means - all it can mean - is that Parliament is saying that it has no intention of exercising its powers in the future in a way that conflicts with Community law. It is announcing these intentions, and asking the courts to take note of it. In other words, it is laying down a rule of interpretation. Future Acts of Parliament are not to be interpreted in a way that conflicts with the supremacy of directly effective Community law." Trevor C Hartley European Union Law in a Global Context (Cambridge University Press, Cambridge, 2004) at 162. A better explanation is given by Alina Kaczorowska: "In Factortame (No.2) and $R$ v Secretary of State for Employment, ex parte Equal Opportunities Commission, the House of Lords (now the UK Supreme Court) established that an "implied supremacy clause" is inserted in any UK Act of Parliament enacted since 1972 to the effect that any inconsistence between the Act and the EU law is resolved in favour of EU law unless Parliament expressly and unequivocally indicates that it intends to derogate from EU law. The "implied supremacy clause" was further explained in Thoburn (Metric Martyrs) in which Laws J made a distinction between constitutional statutes, a superior category of statutes which govern constitutional rights of citizens, and "ordinary statutes". Examples of "constitutional" statutes are Magna Carta, the Human Rights Act 1998 and the European Communities Act 1972 (ECA) ... The doctrine of implied repeal does not apply to constitutional statutes." Alina Kaczorowska European Union Law (2nd ed, Routledge, London, 2013). Now, this elegant balancing act in logic, however subtle and adroit, does not have the force to annul the reality of the facts. Let us explain. Sovereignty has two sides, one "internal" and the other "external". On the "external" side each EU Member State, having freely acceded to the Treaty, is likewise free to withdraw from the Treaty. Moreover, the faculty/right of withdrawal of the Member States is provided for and governed in the text, now for the first time, of the Treaty of Lisbon in art 50(1): "Any Member State may decide to withdraw from the Union in accordance with its own constitutional requirements". The right to accede to the Treaty, when it accords with the national interest, is the mirror image of the right of withdrawal from the Treaty, when demanded by the national interest; these are the two aspects of the "external" side of sovereignty. Here, sovereignty is "strong". But the act of withdrawal from the Treaty - that is, the exercise of the right to withdraw - is the exception. The rule, however, is otherwise. During all the period of abidance within the EU, the Member States are subject to, and cannot but be subject to, all the duties and limits imposed by EU Law. Duties and limitations which are, besides, quite onerous and of vast proportions that even the United Kingdom must withstand, in spite of the opt-out exercised in key areas like the Economic and Monetary Union (EMU) and the Area of Freedom, Security and Justice (AFSG). Then, sovereignty evinces weakness. The "sovereignist" stance (wrongly) identifies the exception as the rule. This reasoning asserts that sovereignty is a possibility that is continuous, and relies on the will of the state. The process of integration, and the acceptance of the limits and duties imposed by the Treaty States depends on the constant will of the Member States. In fact, the entire mechanism of the EU depends on this. In this way, the sovereignty of withdrawal - the "strong" sovereignty - seems to loom like a menacing shadow over the whole EU legal system. The reality however is otherwise. The original six founding countries have been joined over the years by 22 more states. No state has left the Union. All the Member States have had, willy nilly, to become subordinate to the limits on sovereignty that membership of the Union entails. This is how things really stand. Thus, the opinion that maintains that the sovereignty of Parliament reflects "the flexible notion rooted in the political reality of the sharing of power needed in meeting the changing needs of a complex society" appears far more realistic and plausible. See Lord Lester and Lydia Clapinska "Human Rights and the British Constitution" in Jeffrey Jowell and Dawn Oliver (eds) The Changing Constitution (5th ed, Oxford University Press, Oxford, 2004) at 63. In general, on the British constitution under pressure, see Neil Walker "Our Constitutional Unsettlement" (2014) PL 529. 
For the record, it must be mentioned that in 1975 - on the initiative of the Labour Government a referendum was held in the United Kingdom ${ }^{19}$ whereby the British electorate was asked if it wished to leave the EEC. A large majority (67.23 per cent) answered: "no, we do not wish to leave the EEC".

Another occasion where Parliament's sovereignty was weakened occurred in 1997. The period following this date was very important for the constitutional history of the United Kingdom. In 1997, New Labour, led by Tony Blair won the election, thus putting an end to the long period of Conservative government. Tony Blair's New Labour political manifesto had a series of very incisive proposals regarding the United Kingdom's constitutional structure, which were punctually carried out one after the other.

First was the devolution of powers, which is the idea of shifting powers from the centre to the periphery. Second was the Human Rights Act 1998, a statute that incorporated the European Convention for Human Rights into the legal system of the United Kingdom. Third was the reform of the House of Lords, destined to mark the end of the right of inheritance as far as membership of the upper house of Parliament was concerned. Finally, the Supreme Court was set up by the Constitutional Reform Act 2005.

This article will now examine these reforms one by one.

17 The long trek leading the United Kingdom courts to metabolising the supremacy of Community law over United Kingdom law is well reconstructed by Paul Craig "Britain in the European Union" in Jeffrey Jowell and Dawn Oliver (eds) The Changing Constitution (7th ed, Oxford University Press, Oxford 2011) at 102. In particular on the European Union Act 2011, which has in various ways integrated the European Communities Act 1972, see Paul Craig "The European Union Act 2011: Locks, Limits and Legality" (2011) 48 CML Rev 1915; and M Gordon and M Dougan "The United Kingdom's European Union Act 2011: Who Won the Bloody War Anyway?" (2012) 37 EL Rev 3.

18 On the jurisprudence of national courts regarding the relation between EU law and domestic law before the Lisbon Treaty 2009, see the references given by Hartley, above n 16, at 164, n 30. For judgments following the adoption of the EU Treaty of Lisbon, see Jose Maria Beneyto and Ingolf Pernice (eds) Europe's Constitutional Challenges in the Light of the Recent Case Law-Lisbon and Beyond (Nomos Verlagsgesellschaft, Baden-Baden, 2011); Pablo Jose Castillo Ortiz "'Playing the Judicial Card': Litigation Strategies During the Process of Ratification of the Lisbon Treaty" (2014) 20 Eur LJ 630; Jean-Claude Piris The Lisbon Treaty: A Legal And Political Analysis (Cambridge University Press, Cambridge, 2010) at 4963; and David Phinnemore The Treaty of Lisbon: Origins and Negotiation (Palgrave Macmillan, Basingstoke (England), 2013) at ch 8. France: Gerald L Neuman "The Brakes that Failed: Constitutional Restriction of International Agreements in France" (2013) 45 Cornell Int'1 LJ at 257-336. Germany: Elisabetta Lanza "The Core of Stress Sovereignty and Boundaries of European Union's Identity in the Lissabon - Urteil" (2010) 11 German LJ 399. Czech Republic: Ivo Slosarcik "The Treaty of Lisbon \& the Czech Constitutional Court: Act II" (CEPS Policy Brief No 197, October 2009). Hungary: Agoston Mohay "Decision 143/2010 of the Constitutional Court of the Republic of Hungary regarding the Constitutionality of Act CLXVIII of 2007 Promulgating the Lisbon Treaty" (2012) 6 Vienna J on Int'l Const L 301.

19 Referendum Act 1975. See also Cmnd 5925, 1975 and 6251, 1975. 
The United Kingdom, which until 1996 could certainly be considered one of the most centralised states in the world as it knew no form of power sharing, suddenly underwent a process of large scale decentralisation towards Scotland, Wales and Northern Ireland. The modern United Kingdom is a state made up of four nations. This fact is immediately apparent in sport. In soccer, for example, there are "international" representative teams for each of these communities: there is a Scottish team, a Welsh team and a Northern Irish team (whereas at the Olympic Games unity is recomposed in the United Kingdom international team).

The fact is that this radical centralisation of powers in London raised criticism and growing protest. In Scotland, in particular, at a certain point there arose dizzying support in favour of the Scottish National Party. Despite this, in the 1992 election the Conservative Party won with a large majority in the House of Commons, while the Scottish National Party obtained only three seats. This fact was emblematic of a crisis which was under way between London and Edinburgh. As a consequence of the 1992 election, tensions grew high within the United Kingdom about the untenability of an exceedingly centralised state. Increasing opposition to such a centralised state occurred in the ambit of important changes in the Labour Party, which led to the birth of New Labour under the leadership of Tony Blair. Thus the process began with the devolution of powers to Scotland: there was a referendum in 1997 followed by the passing of the Scotland Act 1998, which established the Scottish Parliament (endowed with law-making power) in the Holyrood Building. ${ }^{20}$ In this way a Parliament "competing" with the Parliament of Westminster was created for the first time since the Act of Union in 1707. This created a new limitation to the supremacy of Parliament. After many centuries, we thus have for the first time a sharing of powers in the United Kingdom.

It is important to emphasise that the distribution of competences between Edinburgh and London appears, on its face, to reproduce the typical division found in a federal state. In fact the residual powers clause is favourable to the Scottish Parliament. The "residuum of powers clause" in sch 5 of the Scotland Act 1998 establishes that all matters not explicitly conferred on the central authority, or not to be found in the double list of competences, are not under the authority of London, but of Edinburgh. ${ }^{21}$ But sch 5 must be read together with s 28(7), which keeps the ultimate legislative supremacy of the United Kingdom Parliament safe, stating that "this section does not

20 The Holyrood building is very modern and was designed by a Catalan Architect, Enric Miralles, who comes from a region where there is a strong sense of independence. See the referendum on self-determination of Catalonia held 9 November 2014, the final result of which - pro-independence - seems, however, a largely evanescent efficacy.

21 Jeffrey Jowell and Dawn Oliver (eds) The Changing Constitution (6th ed, Oxford University Press, Oxford, 2007) at 210. On the possible legal consequences of a future withdrawal of Scotland from the United Kingdom, see James Sloan "The International Law Implications for an Independent Scotland: Findings of an Expert Legal Opinion Requested by the UK Government" (2013) 17 Edinburgh LR 224; and Ian Campbell "The 'State', The 'Crown' and the Union of Scotland and England: Reflections on what might become the Sovereign's 'New Clothes" (2014) Jur Rev 165. See also Adam Tompkins "Scotland's Choice, Britain's Future" (2014) 130 LQR 215. 
affect the power of the Parliament of the United Kingdom to make laws for Scotland". This formula could, perhaps, be compared with the "supremacy clause" resulting from art VI(2) of the United States' Constitution, which indicates that if the legitimate powers of the state and nation conflict then those of the national (federal) government shall prevail.

In reality, the asymmetrical devolution arrangements in the United Kingdom in no way resemble a federal model, ${ }^{22}$ even considering the wide devolution of central governmental powers to Scotland. ${ }^{23}$ The United Kingdom is not a federal state at all, nor is it similar to a federal state. Thus another important difference is noted with respect to the United States. Whereas the United States constitutes a federal state, the United Kingdom does not.

Next there was a decentralisation of powers in favour of Wales, which, in the beginning, was not a devolution of legislative powers but only of administrative powers. The decision to give the National Welsh Assembly legislative powers was only made in 2006 and subsequently endorsed by a referendum in $2011 .^{24}$ As a result of the triumph of the Scottish National Party in the 2015 Election, it is likely that the Welsh will also be drawn into this new wave of devolution that will likely occur. New primary legislative powers for the Welsh assembly could very well be transferred.

Finally, in Northern Ireland, the Parliament of Stormont Castle was instituted in Belfast following a much more tortuous path. This Parliament was provided with legislative powers by means of a system of gradual transfer from London. Here, constitutional reform was connected to a peace process. In fact the devolution of powers in favour of Northern Ireland took place following the signing of the Good Friday Agreement in 1998. Moreover, by the Belfast Agreement of 1998 the governments of the United Kingdom and the Republic of Ireland agreed that the future status of

22 It is clear that the conclusion of this point would be quite different if, following Peter Hay Federalism and Supranational Organizations. Patterns of New Legal Structures (University of Illinois Press, Urbana, 1966), one was to take up an old thesis, still widely accepted among the sociologists of politics, which includes within federal systems all the range of societies that can be defined as "articulated". This, however, would mean losing that which characterises federalism and the federal state from the legal point of view

23 Out of curiosity, the thesis of the confederal nature of the Union between Scotland and England was advocated before the Court of Sessions in MacCormick $v$ The Lord Advocate 1953 SLT 255, 1953 SC 396. In this case it was a matter of deciding if the use of the name Elizabeth II by the present Queen was compatible with the Treaty drawn up at the time between England and Scotland and made enforceable by Parliament in London by means of the Union with Scotland Act 1707. The basic thesis - the contractual nature of the Union between Scotland and England - and the corollary that was made to derive from it - of deeming as new the series and progressive numeration of the Sovereigns of the United Kingdom - was disregarded by the Court.

24 Arthur Aughey, Eberhard Bort and John Osmond Unique Paths to Devolution: Wales, Scotland and Northern Ireland (Institute of Welsh Affairs, 2011); Ron Davies Devolution: A Process Not an Event (Institute of Welsh Affairs, The Gregynog Papers 2(2), 1999); Martin Johnes Wales Since 1939 (Manchester University Press, Manchester, 2012) at 412 and 443; and Richard Wyn Jones and Roger Scully Wales Says Yes: Devolution and the 2011 Welsh Referendum (University of Wales Press, Cardiff, 2012). 
Northern Ireland was to be decided on the basis of consent by the people of Northern Ireland and the Irish Republic. ${ }^{25}$

It must be noted that the devolution occurred through Acts of the Westminster Parliament (Devolution Acts). Therefore, once again we can see the peculiarities of the "non-codified" Constitution of the United Kingdom. In any other country in the world a similar decentralisation process would have taken place through amendments to the "codified" constitution. For example, think of the amendments in 2001 to the Fifth Title of the Italian Constitution relating to the reinforcement of regional autonomy. In Germany, the recent reform of the State's federal structure took place following a change of the Grundgesetz. This did not happen, of course, in the United Kingdom. There is no "codified", rigid Constitution placed at the apex of the hierarchy of the sources that needs to be modified in order to introduce reforms of this kind. In the United Kingdom all that is required is a law approved by Parliament, in quite the same manner as any other, to be able to introduce the reforms mentioned above.

Yet it is significant that these laws were preceded by referendums. This led to a doctrinal debate as to whether this procedure - referendum followed by legislative action - was to be considered a "differentiated" law-making procedure in comparison to the ordinary one. The fact remains that we are talking about Acts of Parliament, which, given their content (that is, the law of the territorial distribution of power) are themselves sources of the "non-codified" Constitution of the United Kingdom.

To date there has been at least one judgment, given on 21 November $2012,{ }^{26}$ in which the United Kingdom Supreme Court had to address the problems of conflicting laws (a conflict between a law made by the Parliament of Westminster and another made by the Welsh National Assembly). Regarding the typical role exercised by a supreme court or by an ad hoc constitutional court, which is that of solving conflicts of competence, it is too early to say if this role will be exercised habitually by the United Kingdom Supreme Court, even if there are signs that seem to lead in this direction. Here, it appears that a procedure similar to that of the United States legal system seems to have begun. And perhaps there is a need to reconsider the basic characteristics of the United Kingdom legal system.

The Human Rights Act 1998 (HRA) is an Act of Parliament, which incorporated the ECHR (signed in Rome in 1950) into the domestic legal system. The ECHR was signed by the United Kingdom when it was first drawn up. One must remember, nevertheless, that with regard to the relationship between international law and domestic law, the United Kingdom is a "dualist" state

25 Conor Donohue "Dissertation Proposal: The Northern Irish Question and the Belfast Answer? Self-Determination and the Belfast Agreement" (LLB (Hons) Dissertation Proposal, Victoria University of Wellington, 2015).

26 Attorney-General v National Assembly for Wales Commission [2012] UKSC 53, [2013] 1 AC 792. 
(that is, a state where an international treaty only becomes directly applicable once it is turned into domestic law). Therefore, the ECHR was not applied directly in the United Kingdom until 2000.

In 1998 (when the HRA was passed) the United Kingdom decided to incorporate the ECHR into its legal system through an Act of Parliament. That Act, in a certain sense, nationalised the ECHR, so that it could be applied directly by English judges. A cascade of consequences ensued from this, which undermined the sovereignty of Parliament. In fact, courts are now able, under s 4 of the HRA, to deliver as a "measure of last resort"27 a "declaration of incompatibility" of an Act of Parliament with respect to the ECHR, after having tried unsuccessfully to use their interpretative powers under s 3(1). However, United Kingdom judges are not empowered to repeal or void the laws which are incompatible with the ECHR. Here, formally, the sovereignty of Parliament is respected once again; judges do not have the power to void an Act of Parliament. However, the fact that judges may deliver a declaration of incompatibility (though this has no formal legal consequences but is merely of declaratory value) warning Parliament that it has legislated in conflict with the ECHR, in actual fact amounts to an enfeeblement of the sovereignty of Parliament. ${ }^{28}$ In this regard there have been numerous cases of significant conflict between the courts and the legislature (perhaps, more precisely, the government) regarding the point of inconsistency between legislation and the ECHR. Major problems arose particularly in relation to antiterrorist legislation. A strong conflict sometimes arose between the government, which claims the right/duty to restrict the rights contained in the

27 Ghaidan v Godin-Mendoza [2004] UKHL 30, [2004] 2 AC 557 at [39] and [50] per Lord Steyn.

28 Compared to the mechanism provided for in s 4(2) of the European Communities Act 1972 (the ECA), which seriously undermines the sovereignty of Parliament as understood by Dicey, the distinctive device set up in synergy with s 3(1) of the HRA 1998 - "So far as it is possible to do so, primary legislation and subordinate legislation must be read and given effect in a way which is compatible with the Convention rights" - and s 4(2) - "If the court is satisfied that the provision is incompatible with a Convention right, it may make a declaration of that incompatibility" - seems instead barely to touch on Parliament's prerogatives. In fact, while based on the ECA, judges are authorised to apply EU law in place of the incompatible rule of United Kingdom law, the HRA 1998 obliges judges to apply the domestic rule if incompatible with the Convention rights. However, a problem can occur in relation to the formula "so far as it is possible". If the judge, in the effort to give the rule of primary legislation a "reading" compatible with the Convention rights remains within an "interpretation" in the technical sense, albeit "stretched", "so far as it is possible", the sovereignty of Parliament remains substantially intact. If instead the judge, in an effort to avoid a "declaration of incompatibility", tries to apply the law at all costs, deciding to transfigure its meaning, as at times has happened and can happen, then the conclusion may be quite different. On this point we largely agree with the analysis given by Aileen Kavanagh in her book Constitutional Review Under UK Human Rights Act (Cambridge University Press, Cambridge, 2009) at 92 and following. There is no doubt that the intent of provisions like s 2(4) of the ECA or ss 3(1) and 4(a) and (b) is to meet the need to adapt the traditional British system to the principles and rules of international derivation. It is also in reaction to the phenomenon, observable today, of the redistribution of many traditional state powers, thus included in the concept of sovereignty, onto levels higher than, or at least external to, the state. 
HRA in the name of national security, and the courts which are more concerned with protecting freedom. ${ }^{29}$

Thus one can see how, developing from markedly different constitutional foundations, the two legal systems are slowly approaching one another. As far as their basic characteristics are concerned, it is as if they were icebergs drifting towards each other.

\section{A COMPARISON OF THE TWO CONSTITUTIONS}

Having very briefly described the basic features of the British legal system and having also hinted at the differences and similarities between the two legal systems, it is now appropriate to attempt a true comparison between the two constitutions. The points discussed below are: (a) the sources of law; (b) the form of state; (c) the form of government; and (d) the system of judicial control of legislation. This article has already touched upon these topics in various ways. Now it will analyse them in further depth.

\section{A The System of the Sources of the Law}

According to a famous quote attributed to Winston Churchill, the United States of America and the United Kingdom are "one people divided by a common language" (Queen's English and American English). This is evidently a paradox. Nevertheless we can use this metaphor in relation to the sources of law. The foundational element of the two legal systems (as well as those in other countries of Anglo-Saxon origin) is the same: a legal system based on case law. Yet in-depth analysis discloses remarkable differences, specifically related to constitutional sources. The United States is a country which has a codified constitution dating back to 1787. It is the oldest constitution in the world (previously that had been the Constitution of Iceland, which was quite recently reformed). It is an entrenched, written constitution. The United Kingdom, by contrast, has a "non-codified" constitution within which numerous written and non-written sources coexist. This is the first important difference. It is also the difference between the United Kingdom Constitution (and that of New Zealand and partly of Canada) and that of all the other countries of Anglo-Saxon origin (the ex-colonies).

29 Aligning United Kingdom anti-terrorist laws, before and after the attack on the World Trade Centre of September 2001 (9/11) with freedom and human rights has been a task that the British courts have taken seriously. This was especially so when in 2000 they were empowered to review primary legislation for compliance with the HRA, a codified set of fundamental rights. On this topic, see extensively Richard Stone Civil Liberties \& Human Rights (9th ed, Oxford University Press, Oxford, 2012) at 429-460 and ivi bibliography. Stone - among other things - refers to Lord Hoffman's view in A v Secretary of State for the Home Department [2004] UKHL 56, [2005] 2 AC 68 at [97], who, considering the indefinite detention powers under the Anti-Terrorism, Crime and Security Act 2001 (ATCSA 2001), expressed the opinion: "The real threat to the life of the nation, in the sense of a people living in accordance with its traditional laws and political values, comes not from terrorism but from laws such as these. That is the true measure of what terrorism may achieve. It is for Parliament to decide whether to give the terrorist such a victory." 


\section{B The Form of State}

The form of state deals with the relationship between citizens and the public power, and between authority and freedom.

The United States is a republic, whereas the United Kingdom is a monarchy. Today this difference is of historical value more than anything else. The United Kingdom is a "republican monarchy": on a formal level it is a monarchy, but from a substantive point of view it has all the features of a democratic republic. Nevertheless, the birth of the United States was dominated by the fight for independence from the increased taxes imposed on American colonies by the English Crown. Therefore, there is a monarchy on one side and a republic on the other.

On the level of the territorial distribution of power, too, there are very marked differences between the two legal systems. Generally, it must be noted that the United States is a federal state (in fact the United States constitutes the prototype of the federal state), whereas after devolution the United Kingdom can be considered, at most, a peculiar variant of regionalism (up until 1997, with France, it had been one of the most centralised democratic states). More generally, the United States of America is the result of what Carl Friedrich, a prominent Harvard political scientist, called a federalising process. ${ }^{30}$ This is the process of gradually moving toward greater aggregation between member states: from the primitive confederation to "dual federalism" to "cooperative federalism". In fact, today, many countries that define themselves as being "federal" are the result not of a bottom-up process but of a top-down process. In other words, there are countries which have gone from being a unitary state to being a federal state, in the so-called "linguistic federalism".

There are also more specific differences. In the United States of America there is a "classic" federation where one of the most important features is the symmetry among member states. It is in fact a highly symmetrical system. The relationship between the central government and the states is such that the states are equal regardless of their territorial size or their population. This equality can be measured at different levels:

The first is the "residuum of powers" clause in favour of the member states. In the United States of America law-making power is exercised both at a federal level and at a state level. Here, all the member states are on par in the sense that the distribution of law-making powers between the centre and the periphery confers the same powers to each state.

The second element is the presence of a second House of Parliament where the member states are represented. In the United States constitutional system the states are represented in the Senate, which can be defined as the House of the States. The 17th Amendment, which was adopted in 1913

30 CJ Friedrich Trends of Federalism in Theory and Practice (Frederich Praeger, New York, 1968). It should be noted that a remarkable experiment in a sui generis federalising process appears to be underway in Europe, where the EU seems to be moving toward an ever closer union, although this is being slowly and strongly resisted. 
to modify art I(3), cls 1 and 2 of the Federal Constitution, ${ }^{31}$ provided for the election of the senators by the people of states, rather than state legislatures. In the Senate, the representation of the states is equal regardless of territorial extent and population density. Each state has two senators elected by the population of each state (a total of 100 senators for 50 member states). For example, Hawaii and California each have two senators. This is one of the constituent principles of the Federal Compact signed in Philadelphia in 1787. Even in the House of Representatives, where the representation is, in theory, based on population density (which should mean the number of representatives is proportional to the population of each state) this does not happen in reality. There is greater weight given to the small states, and in particular to the medium states, in comparison to the larger states. In other words, California and Texas are under-represented with respect to other states, such as New Hampshire or Wyoming. This is further illustrated in a very important aspect of United States constitutional life: the election of the president of the United States.

This principle of equality of representation does not constitute a general rule in federalism. In Germany, for example, the representation in the Bundesrat - which corresponds to the United States Senate - reflects the size of the Länder (state), and the representatives are nominated by the governments of the states, rather than by the public. In this case, the "federal" House is constituted using a completely different standard to that in the United States.

As well as an equal distribution of law-making powers, there is also distribution of judicial power. This is displayed with particular clarity in the United States of America, in the sense that there are significant differences between member states, with regards to the judiciary, and to criminal procedure and criminal law. From this point of view, the greatest difference is seen in the ambit of capital punishment, related to an extremely basic right: the right to life.

Last but not least, a particularly important point arises in connection with constitutional amendment. Here, two elements become intertwined: federalism, and the rigid character of the United States Constitution, which requires that amendments to the Constitution be adopted only through a procedure requiring a wider consensus than that for the approval of any other law. Here the "federal" aspect comes into play in the sense that in order to modify the Constitution the participation of the member states is necessary. This is in contrast to what is required in other countries that have a marked territorial decentralisation of power. This fact proves yet again that the

31 In truth, from a formal point of view the 17th Amendment seems to void of any foundation the deemed "inter-State" character of the United States Senate. The 17th Amendment changed the original wording of the Constitution: "The Senate of the United States shall be composed of two Senators from each State, chosen by the legislature thereof..." (art I(3), cl 1), with a different rule whereby the senators assigned to each state are "elected by the people thereof ...". Nevertheless the Senate continues in practice, far more than the House of Representatives, to heed the demands of the States' rights. Furthermore it is significant that the 17th Amendment altered only the elective criteria of the Senate, while leaving in place the principle of equal suffrage - albeit this principle, once direct election by the people of Senators had been provided for, could have been thrown aside. 
central government and the member states are placed on an equal footing. To modify the original federal constitution, the consent of both the central government and of the majority of the member states is necessary. Other federal states generally apply similar amending procedures, such as Germany and Australia.

Regarding the territorial organisation of power - the form of state - the United Kingdom of today is decidedly different from the United Kingdom of pre-1997. Nevertheless, even if today the United Kingdom presents itself as a "compound" state (a "compound" state, a devolved state or whatever else we wish to call it), enormous differences remain between the United States of America and the United Kingdom. Whereas the United States of America is a typical example of a federal state, particularly characterised by a symmetrical relationship between central government and member states, the United Kingdom arises from a devolution which presents itself in the shape of asymmetrical decentralisation; in other words, it is a question of differentiated regionalism. This means that the Westminster Parliament, composed of the House of Commons and the House of Lords, not only legislates for the entire United Kingdom in the ambit of matters reserved for the central state, but also legislates for England alone. There is thus a primary asymmetry of a functional character, accompanied by a structural asymmetry. There is no English Parliament such as there is a Parliament of Wales, a Parliament of Scotland and a Parliament of Ulster (Northern Ireland). Nor are there any legislative assemblies for the various English regions (the institution of which had been proposed: for the North-East, for Cornwall, for Yorkshire and so on). This fact has brought about a rather bizarre situation. The fact that the Parliament of Westminster legislates also for England means that a problem immediately arises. Within the Parliament of Westminster sit Members of Parliament elected in England but also Members of Parliament elected in Scotland, Wales and Ulster (Northern Ireland). Whence there arise a series of paradoxical situations, where laws destined to be enforced only in England have been approved thanks to the votes of Members of Parliament elected in Scotland. This happened, for example, with the British National Health Service (NHS) reform for which a process of semi-privatisation had been scheduled. It was a very controversial reform proposed by the Labour Government which caused some Labour backbenchers to rebel. Nevertheless it was passed thanks to the votes of the Labour Members of Parliament elected in Scotland, where the reform would not be applied.

\section{The Form of Government}

Another significant difference between the United States constitutional system and that of the United Kingdom is the form of government. In this regard, the United States of America and the United Kingdom are at opposite poles: the United Kingdom is "the cradle of parliamentary government"; it is the prototype of the parliamentary form of government. In contrast, the United States of America is the prototype of the presidential form of government.

In relation to doctrine, there is a discussion as to why the adoption of the presidential form of government was preferred in the United States of America. Some scholars believe that although the Founding Fathers wished to differentiate the United States system from the English one, they were 
somehow influenced by the model of the English government as it functioned at the time of the War of Independence.

The situation of political institutions in England at that time was the following: Parliament (the House of Commons) - the elective body - exercised legislative power; the executive power was in the hands of the King who was legitimised "from above". In other words, England was a constitutional monarchy. When the "Founding Fathers" wrote the Constitution in Philadelphia, they adopted the presidential system, where the President is not legitimised from above, like the English King, but from below, by popular election. So, the form of government chosen by the Founding Fathers is, in their view, nothing other than the republican version of the English model of government at that time. ${ }^{32}$

Today, the two systems of government are more distant than ever. This evolution began in the United Kingdom in 1782, when for the first time a situation occurred in which a Prime Minister, Lord North, was forced to resign against the wishes of the King. The Prime Minister had lost the confidence of Parliament over the protests that snaked into the House of Commons about the growing and, finally, no longer tolerated power acquired by George III during the government of Lord North. Historically, Lord North may be considered the first head of government to suffer a motion of no confidence from Parliament. King George III was obliged to appoint the Whig Charles Watson-Wentworth, the 2nd Marquess of Rockingham, who was supported by the majority of Parliament, as the new Prime Minister. This is the seed of what we call parliamentary government. ${ }^{33}$

32 See Charles Howard McIlwain Constitutionalism and the Changing World (Cambridge University Press, Cambridge, 1969); and Harold Stannard The Two Constitutions: A Comparative Study of British and American Constitutional Systems (Adam and Charles Black, London, 1949). We agree with this view, although not completely. Each of these unidimensional views provides only one aspect, perhaps very importantly, of the reality, which - instead - is always multidimensional. The United States Constitution is not only the product, updated and corrected, of the English experience at that time. The United States Constitution, in its essential aspects, is also the distillation of other experiences of constitutional theories. For example, we can say with reasonable certainty, according to an unchallenged tradition of historical studies, that no other political theory had a greater influence on the thinking of the United States Founding Fathers when they drafted the United States Constitution, even more than that resulting from the English constitutional experience of their time, than that of "mixed constitution" directly derived - through the writings of Polibius - by the peculiar government of republican Rome (509-48 BCE). Such a modelling of the United States' Constitution on the constitutional structure of republican Rome gave to the United States Republic its own unique and incomparable way of operating.

33 This interpretation of the resignation of Lord North as a turning point of the English constitutional history, we draw from AM Wilshere An Analysis of Taswell-Langmead's English Constitutional History (Sweet \& Maxwell, London, 1919) at 120-121: "Under Lord North the personal influence of the king attained its highest pitch. He directed all matters of policy, supervised the management of debates in parliament, reserved for himself all the patronage, arranged the whole cast of the administration, nominated and promoted judges, gave and refused titles, honours and pensions. To enforce his authority he professed himself ready to adopt extreme measures; several times he even threatened to abdicate. At last in $1780 \mathrm{Mr}$. Dunning carried in the House of Commons his resolution 'that the influence of the Crown has increased, is 
As to the principle of separation of powers, one can notice that it is respected much more in the United States than in the United Kingdom. In the latter, one can speak not so much of the separation between the legislative and the executive, but rather of that between parliamentary majority and the Opposition (in the sense that it is the government that legislates by means of its majority). In terms of centrality of institutional articulation of power, the British Prime Minister is much stronger than the United States President. A United States President is often confronted with a Congress in which the opposition party prevails - the so-called "lame duck" President.

\section{Constitutional Adjudication}

Obviously there is a strong connection between the form of constitution and constitutional adjudication. In the United States judicial review prevailed, dating from Marbury $v$ Madison, ${ }^{34}$ regarding a federal law, and from Fletcher $v$ Peck, ${ }^{35}$ regarding a state law. There is a control of constitutionality not exercised by an ad hoc court (like the "Kelsenian" type of constitutional court), but by the individual judges and the Supreme Court in the last resort. In the United Kingdom a similar type of control does not exist, although an exercise of the state's functions at different levels has recently begun to be established. At this point adjudication is required to ascertain the true extent of the power conferred. This need can be independent of the safeguard of the constitution. That is to say, in the United Kingdom legal system, devolution can also affect the role of the Supreme Court.

increasing, and ought to be diminished,' and in 1782 Lord North was compelled to resign." Then George III was compelled to accept as Premier the Marquis of Rockingham, a strong leader of the Whig party. See also Thomas Pitt Taswell-Langmead English Constitutional History (10th ed, revised and enlarged by Theodore Pluknett, Sweet \& Maxwell, London, 1946) at 717. On this topic, see also Ian R Christie The End of North's Ministry, 1780-1782 (St Martin's Press, New York, 1958). See also Peter DG Thomas Lord North (St Martin's Press, New York, 1976).

34 Marbury v Madison, above n 9.

35 Fletcher $v$ Peck 10 US 87 (1810). 
